experience rating account with benefits paid under such circumstances. Patently, the employer's fault or lack of fault should not enter into the determination..$^{32}$

6. Causes of Unsuitability Personal to the Claimant. IThile it has been stated that the cause for the unsuitability must be found in the work itself and not in the domestic or personal situation, ${ }^{33}$ it is submitted that causes personal to the claimant should be held sufficient. Suitability is a relative matter in which the effect of the work upon the claimant and his normal economic activity and activity in society should be considered. Thus, where a claimant would have been required to leave her child alone were she to take a job on a particular shift, such job is unsuitable for her.

Even were it to be admitted that the suitability provision required that the cause must be found in the work itself, the requirement that disqualification may only occur where the refusal is aithout good cause provides a basis for questioning a narrow view. It seems patent, for example, that the impossibility of leaving one's children should constitute good cause for a refusal. ${ }^{34}$

\title{
Disqualifications for Voluntary Leaving and Misconduct
}

\section{KATHERINE KEMPFER广}

ALL the American unemployment compensation laws contain disqualifications for voluntary leaving and discharge for misconduct. Under the original laws, with few exceptions, the disqualifications took the form of a postponement of benefits. However, the number of states which, in addition to postponing benefits, also reduce the claimant's maximum benefit amount has been steadily growing. ${ }^{1}$

32. See Simrell, Employer Fault vs. General Wrelfare as the Basis of Unemploymert Compensation, page 181 infra.

33. In Ben. Ser. $8995-N . H . ~ R(V 7-12)$ it is stated: "The cause for refuring the worl: must be because of the work itself and not because of a domestic situstion." In Ben. Sar. 9215-Ga. A (VS-3), the referee held ". . . that for good personal reasons not connected with the work [a claimant] refused to accept suitable work and is, therefore, subjoct to a disqualification for the week in which he refused the transfer and 4 additional weels, with two times his weekly benefit amount charged against his available credits."

34. Of course, under some such circumstances one may be held unavailable.

$\dagger$ Attorney, Federal Security Agency.

1. Voluntary learing: As of December 31, 1937, 45 states merely postponed benefits while five also reduced or cancelled benefit rights. (At that time New Yorl: had no voluntary quit disqualification.) As of September 30,1944, the number of states in the latter group had increased to 20 .

Misconduct: As of December 31, 1937, 44 states merely postponed benefits and sis added reductions or cancellations of benefit rights. As of September 30, 1944, the latter 


\section{Theories of Disqualification.}

Various theories of the purpose of such disqualifications have been suggested: to penalize and thereby discourage commission of the disqualifying acts; to limit benefits to risks which can be insured on a sound actuarial basis; to limit the risks to involuntary unemployment due to lack of suitable work.

Penalty Theory. Some of the present disqualification provisions, particularly those canceling wage credits and reducing maximum benefits, are so severe as actually to be penalties. As penalties, however, they are logically inconsistent with any theory of punishing or discouraging the commission of specified acts, since of those persons who commit the disqualifying acts only those who seek unemployment benefits are punished. Unemployment compensation laws do not apply statutory sanctions to voluntary quitting and misconduct as such, but only in connection with claims for benefits. Moreover, under American traditions of individual freedom, the proposition that government should not attempt to tie a worker to his job through pressure exercised by law (except in time of war) seems hardly debatable. While workers are undoubtedly discouraged to some extent in seeking changes of employment by fear of loss of rights to unemployment benefits, this is not and should not be the primary purpose of disqualification provisions.

Actuarial Theory. The actuarial theory attempts to explain the voluntary-quit and misconduct disqualifications as based on estimates of tax collections and the cost of insuring various risks. Where the funds available are not sufficient to pay benefits for all unemployment, there is a logical justification not only for limiting the maximum duration of compensation but also for paying benefits to the most deserving (not necessarily the neediest) unemployed persons and excluding the least deserving. The voluntary-quit and misconduct disqualifications may represent a rough attempt to make such a separation. However, the place where the line is drawn does not seem to have been based on any mathematical determination. At the time the acts were originally

group had increased to 21 states. At the time of writing, legislative sessions are still in progress in a number of states. Among the 1945 amendments available, there are no additional provisions for reduction or cancellation of benefit rights. Minnesota no longer cancels wage credits and West Virginia has modified its law to permit restoration to the original maximum benefit amount when a claimant who has been disqualified for voluntary leaving or misconduct returns to work in covered employment during his benefit year. Oregon, however, increased the length of its disqualification from a discretionary period of three to five weeks to all weeks subsequent to the leaving or discharge until the individual has earned at least $\$ 50$ in subsequent bona fide employment and has been employed in subsequent bona fide employment in two separate weeks. Reductions in benefits vary from one or more weeks to complete cancellation of all wage credits earned from the employer whose service the individual left or by whom he was discharged. South Dakota does not suspend benefits but cancels all wage credits earned from the separating employer. 
drafted, reliable data on which to base estimates of the cost of insuring various risks was scanty; census figures used by the Committee on Economic Security in estimating costs of benefits were classified solely by relative duration of unemployment, although some attempt was made to estimate the number of unemployed persons who would be disqualified under suggested provisions. ${ }^{2}$ While there thus seems to have been very little statistical basis for the original disqualification provisions, there is even less actuarial foundation in the case of amendments. During a period in which unemployment was steadily decreasing and the size of the state funds constantly growing, there was nevertheless a trend toward harsher disqualifications.

Causal Theory. The most generally accepted theory is that the disqualifications for misconduct and voluntary learing, like the disqualification for refusal of suitable work and the availability requirement, are intended to carry out the general purpose of unemployment compensation to pay benefits to persons involuntarily unemployed due to lack of work or unemployed "through no fault of their own." 3 It is reasoned that where a.worker has become unemployed through his own act, his unemployment at least for a limited period can be said to be due to that act. That the misconduct and voluntary leaving disqualifications grew out of the general purpose of paying benefits to persons involuntarily unemployed seems sound. The tracing of the initial cause of the unemployment to the voluntary act of the worker does not, however, explain the limitations on the disqualifications. At present no state disqualifies all workers who quit work voluntarily or are discharged for an act which they lnew would result in discharge. In the great majority the misconduct disqualification is limited to discharge for misconduct connected with the work. ${ }^{4}$ The voluntary

2. Williamson, State Actzarial Problems inz Uncmployment Componsation (1930) 3 Law s. Contemir. Prob. 36.

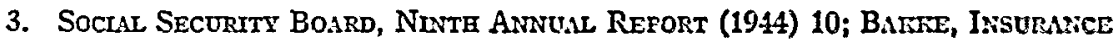
OR Dole? (1935) 52-6; Douglas, Standardos of UNesmpoyurest Insurance (1933) 62-4. See also Report to the PREstDent of the Cosirttee on Econosic SEcurity (1935) $11,21$.

4. Forty-four states as of the close of the 1943 legislative sessions. Five other statutes use substantially equivalent language-discharge for misconduct occurring in the cours: of the individual's work (Connecticut, District of Columbia); discharge attributable solely to deliberate misconduct in wilful disregard of the employing unit's interest (Delaware, Mlassachusetts); discharge for misconduct connected with the work or for misconduct which interferes with and adversely affects his employment (Minnesota). Ohio disqualifies in cases of discharge "for just cause connected with the individual's work." Frior to 1015, Pennsylvania had no statutory disqualification for discharge for misconduct, but the commission of an act which the worker knew would result in discharge was there construed to be a voluntary quit. See, e.g., Ben. Ser. 8855-Pa. R (V7-10). See also Department of Labor and Industry v. Unemployment Comp. Bd. of Rev., 143 Pa. Super. 246, 24 A. (2d) 667 (1912), Ben. Ser. 7465 (V5-7). The South Carolina statute ras amended in 1945 to broaden the disqualification from misconduct connected with the worl: to misconduct "found by the commission to have constituted reasonable grounds for discharge." 
leaving disqualification is limited in many states to voluntary leaving without good cause and in the others to voluntary leaving without good cause "attributable to the employer," "involving fault on the part of the employer," or "connected with the individual's work." Where the worker's discharge is due to an intentional act which he knows will result in dismissal, the causal connection between the act and the unemployment immediately following exists regardless of whether or not the act was misconduct connected with the work. Similarly, whenever the worker's reasons for quitting a job are not so compelling as to make his leaving involuntary, there is a causal connection between his act and his immediate unemployment regardless of his reason for quitting.

The "good cause" limitation on the voluntary quit disqualification and the "connected with the work" limitation on the disqualification for discharge for misconduct seem to have been based, not on a strictly logical analysis of the voluntary or involuntary character of either the initial or the continuing unemployment, but on broader social considerations. Unemployment compensation is limited to "involun. tary" unemployment because public opinion would not support the payment of benefits as a matter of right to persons "voluntarily" unemployed. But public opinion is not concerned with metaphysical theories of causation or free will. People are shocked at the payment of benefits only when the conduct which led to the claimant's unem. ployment was unreasonable, that is, when the claimant was "at fault." Most people would object to payment of compensation to individuals who have arbitrarily quit work or who have deliberately disobeyed reasonable working rules of the employer. On the other hand, probably everyone would agree that it is reasonable for a worker to quit when his own health is in danger or when he is needed at home to care for a sick member of his family, and that it is reasonable for a woman to marry even though her employer has a rule against retaining married women. In such cases most people would not be shocked by the payment of benefits to those individuals when they again become available for work but are unable to find work. One of the factors which influences, consciously or unconsciously, the popular judgment as to whether a claimant should be entitled to unemployment benefits is whether his conduct is consistent with a genuine desire to work and

5. As of the close of the 1943 legislative sessions, 32 states had an unlimited good cause provision. At that time, ten states restricted good cause to causes attributable to the employer, one (West Virginia) to causes involving fault on the part of the employer, and six to causes connected with the individual's work. Connecticut imposes a disqualification for leaving work "without sufficient cause which is either connected with his employment or is, solely by reason of governmental regulation or statute, beyond his control." The Ohio disqualification applies to voluntary quits "without just cause in connection with his work." 
to be self-supporting or whether it indicates that the claimant is seeking to take advantage of his benefit rights in order to have a "vacation" from work.

In order to give effect to generally accepted riews of social policy regarding justification for quitting work and behavior as an employee, it is essential that the voluntary-leaving disqualification recognize good personal cause for quitting work, and that the misconduct disqualification be limited, to misconduct connected with the work. Individuals who quit without good cause or who have been discharged for misconduct connected with the work have acted in a way most people consider unreasonable. But when an individual has a socially approved reason for learing work or has been discharged for some act not connected with his work, it cannot be said that his conduct is inconsistent with a general willingness to work. Laws which restrict good cause for quitting to causes attributable to the employer or connected with the work have lost sight of the basic social purpose of paying benefits to persons whose unemployment is due to lack of suitable work. Such laws reflect a tendency to make the payment of benefits dependent on a particular employer's fault in causing unemployment. ${ }^{6}$

While the causation theory is not a complete explanation of the scope of the disqualifications, it is important in determining their length. The length of disqualification provided by statute represents the legislative judgment on the question of how long the initial cause of the individual's unemployment continues to be the dominating cause. In some states the law fixes an exact number of weeks; ${ }^{7}$ other statutes give discretion to the state agency to fix the length of disqualification in each case within prescribed minimum and maximum limits. ${ }^{5}$ While the question is one of judgment and is not susceptible to exact proof, it would seem that, except for a brief period of unemployment incidental to any change of jobs, the length of unemployment of an individual who is seeking work is more likely to be due to labor market conditions than to the reason for his separation from a previous job. In a "buyer's market" employers might prefer not to hire a worker who had voluntarily quit his job or been discharged for misconduct. On the other hand, when there is a scarcity of labor, the worker's

6. See Harrison, Statutory Purpose and "Inedantory Uncmployment" page 117 supra; Simrell, Emplojer Fault rs. General Welfare as lize Basis of Unemployment Comparsitionz, page 181 infra.

7. As of the close of the 19.13 legislative sessions, in the case of voluntary leaving, 21 state laws fixed a period ranging from one week to the entire period of unemployment following the leaving; in the case of misconduct, fifteen states used a period ranging from three weeks to the duration of unemployment following the discharge.

8. As of the close of the $19 \pm 3$ legislative sessions, in the case of voluntary leaving. the maximum period ranged in 28 states from four to sisteen weels; in the care of misconduct, 34 states used a maximum varying from one to sisteen veeks. 
record in that respect would not be apt to affect his chances of getting a job. Thus the length of his unemployment is largely the result of factors outside his control. Statutes imposing or permitting long periods of disqualification penalize a worker who misjudges labor market conditions and tend to reduce the mobility of labor. At the present stage of public opinion a disqualification limited to four or, at most, six weeks would seem economically and socially desirable.

Statutes which cancel wage credits and/or suspend benefit rights of an individual who has voluntarily left his employment with or been discharged for misconduct by an employer in his base period or any employer whose experience rating account would otherwise be charged with benefits are subject to criticism for looking at causation from the viewpoint of the employer rather than of the employee. The fact that an employer whose account would be charged with benefits paid a claimant is not responsible for the latter's unemployment should not determine the claimant's right to benefits. ${ }^{9}$ Statutes which apply an extended waiting period from the time a claim is filed rather than starting the disqualification period from the date of commission of the disqualifying act have also misconceived the causation principle. Such statutes are apparently based on the theory that, when an individual quits without good cause or is discharged for misconduct, all his unemployment, until he gets another job, is due either to his disqualifying act or to the lack of suitable job opportunities and that until he has been subjected to a period of exposure to job opportunities, as evidenced by the filing of a claim, the disqualifying act continues to be the cause of his unemployment. However, the possible reasons for unemployment of an individual are more varied. The fact that until he files a claim and registers for work he is not exposed to job opportunities ${ }^{10}$ does not mean that his unemployment continues to be due to an act which may have occurred many weeks before. After the limited period during which the disqualifying act can be considered to be the principal cause of an individual's unemployment, other factors become dominant. Where a claim has been filed, the dominating cause may be lack of work; where, because the individual is ill or for some other reason, no claim has been filed immediately following the separation from work, the dominating cause of his unemployment would seem to be the illness or such other factor. After the disqualifying act ceases to be the dominating cause of a claimant's unemployment, whether or not his unemployment is due to lack of suitable work should be tested by the availability requirement.

9. See Simrell, Employer Fault vs. General Welfare as the Basis of Unemployment Compensation, page 181 infra.

10. Filing of a claim is of course not the only way an individual may expose himself to job opportunities. He may seek work through his union, private employment agencies, advertising, direct contacts with employers or in other ways. 
If the causation principle is followed logically, no disqualification will result where the causal connection between the act and the unemployment has been broken by intervening employment. A number of statutes expressly provide that the voluntary-leaving and misconduct disqualifications shall apply only to a leaving of the individual's "most recent work" and a discharge for misconduct connected with the individual's "most recent work," or that the individual shall be disqualified only for consecutive weeks of unemployment immediately following the quit or discharge for misconduct. ${ }^{11}$ In the absence of express statutory provision, the purpose of the laws is best carried out by applying a disqualification only when the original leaving or discharge for misconduct continues to be the cause of the individual's unemployment. When an individual has quit or been discharged for misconduct, obtains another job, and then again becomes unemployed, the question whether the original learing or discharge continues to be the dominating cause of the individual's unemployment can arise only when the second job terminates within the maximum disqualification period and within the period the first job would have continued. The causal connection, of course, continues when surrounding circumstances indicate that the second job was a sham, or when the second job was known by the individual to be temporary. 12 In other cases it would seem that the effect of leaving or being discharged from the first job is too remote and speculative to have a reasonable relation to the worker's later unemployment. ${ }^{13}$ This is certainly true where a worker leaves one job in order to accept a better offer which he believes to be permanent and is later laid off for lack of work.

An understanding of the purpose of the disqualifications vill go far in preventing interpretations which are harsher than required by the language of a particular statute, although in some states amendment of the disqualification provisions, as recommended by the Council of State Governments, ${ }^{14}$ will be necessary to insure the payment of compensation for involuntary unemployment.

11. The second type of statute is preferable since a disqualification, even though already assessed, is automatically terminated by intervening employment of a duration such that in any week the claimant does not meet the statutory test of "unemployment."

12. But $c f$. Ben. Ser. 999-Pa. R (V2-2).

13. Ben. Ser. 7459-Mass. A (V5-7); Ben. Ser. 7S65-Mich. A (V6-3), af'd, Mlich. App. Bd., AD-\$636-912 (unpublished).

14. See Council of State Governaents, Unemployment Cospe:isation in the Postwar Period (1941) 1:

"Each state should re-examine its statutory provisions governing disqualifications to be certain that the penalties imposed do not restrict the right of an individual to change his work for good perzonal or family reasons, and that the manda= tory character of penalties does not produce the unintended effect of denying compensation to the involuntarily unemployed person who is able and villing to vorl:. Specifically, it is recommended that penalties for disqualification entail the suspension rather than the cancellation of benefit rights." 


\section{Voluntary Leaving.}

Any of the various forms of disqualification for voluntary leaving may raise problems as to whether a particular separation was a "leaving" of the individual's "work" and whether it was "voluntary." 16 Where there is no leaving or where it is involuntary, and a holding that the disqualification is inapplicable can be based on the alternative ground of good cause, it is of minor importance which ground is adopted. But in jurisdictions which limit the good-cause justification, a correct determination under the statute frequently requires close analysis of the questions whether there actually was a "leaving" 10 of the individual's "work" and whether it was voluntary.

It is hardly subject to dispute that "leaving work" refers only to a severance of the employment relation and does not include a temporary interruption in the performance of services. Unemployment compensation is not concerned with employer-employee relations until the worker becomes unemployed, and then only with acts which cause the unemployment. An employee who is temporarily absent without authorization may return to find that he has been discharged or that there is no longer any work available. If he is discharged, a question may arise as to whether the act constituted misconduct connected with the work. If there is no longer work for him, his subsequent unemployment is due to that cause and not to his prior absence. Accordingly, benefit decisions hold that absence from the job is not a leaving of "work" where the worker intends merely a temporary interruption in the employment and not a severance of the employment relation. ${ }^{17}$ There may, of course, be difficult questions of fact as to whether or not the worker intended to sever the employment relation.

Webster defines "voluntary" as:

"1. Proceeding from the will, or from one's own choice or full consent; produced in or by an act of choice; as voluntary action.

" 2 . Unconstrained by interference; unimpelled by another's influence; spontaneous: acting of oneself or itself; free." 18

15. The Connecticut statute omits the word "voluntarily" and reads "left work without sufficient cause which either is connected with his employment or is, solely by reason of governmental regulation or statute, beyond his control . . . ." ConN. GEN. STAT. (Supp. 1939) $\S 1339$ e(b)(2), as amended by Gen. Stat. (Supp. 1943) $\S 710 \mathrm{~g}$. At least one Connecticut decision has relied on the omission of the word "voluntarily" in this section of the law. Ben. Ser. 8148-Conn. R (V6-9). However, a California case construing the state labor dispute disqualification furnishes precedent for reading the word "voluntarily" into the phrase "left work." Bodinson Mfg. Co. v. Employment Comm., 17 Cal. (2d) 321, 109 P. (2d) 935 (1941).

16. A "leaving" is the opposite of a discharge or lay-off and is also to be distinguished from an expiration of the employment contract by its own terms. Ben. Ser. 7217-Colo. A (V5-4); Ben. Ser. 4644-Iowa A (V3-10); Ben. Ser. 9110-W. Va. A (V8-1).

17. Ben. Ser. 7011-D.C. A (V5-2); Ben. Ser. 8218 Ind. A (V6-11); Ben. Ser. 7576. Iowa A (V5-9).

18. Webster's New International Dictionary (2d ed., unabridged, 1944). 
It is clear that a leaving is not voluntary where a worker has no choice but to sever his employment, as, for example, where the leaving is necessary to comply with a governmental regulation, ${ }^{10}$ or when the worker has suffered an incapacitating illness or accident and is unable to obtain a leave of absence. ${ }^{20}$ Benefit decisions have also held that a worker's leaving is not voluntary when his reasons are so compelling that he has no reasonable choice. The Massachusetts Board of Review held that the claimant need not have been actually incapacitated at the time she quit in order to make her leaving involuntary; it was sufficient that poor health made a rest necessary to prevent a complete breakdown. ${ }^{21}$ Other cases have held that the claimant's leaving was not voluntary when continuance in a particular job was rendered impossible or impracticable by the existence of a definite risk to health or safety,,$^{22}$ or by inability to obtain transportation, ${ }^{23}$ secure adequate housing, ${ }^{24}$ or make a living at the job. ${ }^{25}$

In considering whether an individual has good cause for leaving his job, there is a large area which overlaps the disqualification for refusal of suitable work. Nearly all statutes list certain criteria to be considered among other factors in determining the suitability of work s $^{\text {s }}$ and some expressly provide that the same criteria shall be considered in determining the existence of good cause for voluntary leaving. Even without an express statutory provision, one would expect that a worker would not be disqualified for leaving work which he might have refused to accept on the ground of unsuitability. This is the usual rule $^{27}$ and is followed even under laws which limit good cause for vol-

19. Ben. Ser. 7983-R. I. A (V6-5) (induction into army); Ben. Ser. 7971-Hawaii A (V6-5) (evacuation by military authorities); Ben. Ser. 7939-N.D. A (V'G-5) (statute abolishing home work).

20. Ben. Ser. 7866-N. H. R (V6-3); Ben. Ser. 6640-Ohio A (V4-11); Ben. Ser. S602Texas A (V7-6); Ben. Ser. \$360-W. Va. A (V7-1). In such circumstances an alternative holding that there was no "leaving." since the separation was due to action of the employer rather than of the employee, would be sound. There could be no disqualification for a discharge since in such circumstances absence from work would not be misconduct.

21. Ben. Ser. 7822-Mass. R (V6-2).

22. Fannon v. Federal Cartridge Corp., 18 N. W. (2d) 249 (Minn. 1945); Ben. Sor. 750S-Colo. A (V5-9); Ben. Ser. 7567-Idaho R (V5-9); Ben. Ser. 3027-MIass. A (V3-3); Mitchell v. Division of Unemployment Comp., Mass. D. C. Jan. 14, 1943, Ben. Ser. 8074Mass. Ct. D (V6-7); Ben. Ser. 7825-Mich. A (V6-2); Ben. Ser. S075-Mich. R (V6-7).

23. Ben. Ser. S028-Mass. A (V6-6); Ben. Ser. 8356-N.C. A (V7-1); Ben. Ser. 7139-Pa. A (V5-3), affd, Pa. Bd. of Rev., B-14-2RB-313 (unpubliched); Ben. Sor. S466-1Wach. $A(V 7-3)$.

24. Ben. Ser. S564:W. Va. A (V7-5),

25. Ben. Ser. 7678-Ark. A (V5-11).

26. While the statutory disqualification for refusal of suitable worls is limited (exeept in Ohio) to refusals without good cause and the statutes thus apparently distinguish betwean factors which make work unsuitable and factors which constitute good cause for refusal of suitable work, in practice there is only slight distinction. See Mienard, Refusal of Stsilatle Work, page 134 supra.

27. Ben. Ser. 6471-Ind. A (V4-9); Ben. Ser, 3287-ilaine A (V3-4); Ben. Sar. 1522Mich. A (V2-5); Ben. Ser. 4305-R. I. A (V3-8). 
untary leaving to causes attributable to the employer or in connection with the work. ${ }^{28}$ To the extent that, under such laws, unsuitability of the work is not held good cause for leaving, the disqualifications or the applications of them are logically inconsistent. ${ }^{29}$

Many reasons in addition to those which make the work unsuitable constitute good cause for leaving work. Some of these, such as an impending lay-off, ${ }^{30}$ a substantial breach of contract by the employer, ${ }^{31}$ or a reasonable grievance against the employer, ${ }^{32}$ justify a leaving even in states having limited good cause provisions. A large group of socially approved reasons for leaving work, however, can relieve a claimant of the disqualification only if personal good cause is recognized. Examples are quitting because of illness or accident (where not caused or aggravated by the physical conditions of the work), ${ }^{33}$ to take care of a sick member of the family where the reason is not so compelling as to make the leaving involuntary, ${ }^{34}$ to retire, ${ }^{36}$ to take another job, ${ }^{36}$ to attend a school or training course, ${ }^{37}$ or to join one's husband in another community. ${ }^{38}$

28. Ben. Ser. 8115-Ariz. R (V6-8); Ben. Ser. 7135-Colo. A (V5-3); Ben. Ser. 7922Mich. A (V6-4). In Fannon v. Federal Cartridge Corp., 18 N. W. (2d) 249, 252 (Minn. 1945), the Minnesota Supreme Court, in holding that a claimant who became seriously ill as a result of contact with gunpowder in her work had good cause attributable to the employer for leaving work, stated: “. . . Mason St. 1944 Supp. $\$ 4337-27(\mathrm{E})(1)$, in prescribing rules for determining whether work is suitable for an unemployed individual, provides that 'the director shall consider the degree of risk involved to his health, safety, and morals, his physical fitness * * *' Under this section, a claimant cannot be disqualified for refusing to accept employment which may be a risk to or endanger his health. If this be true, then certainly it is unreasonable to hold that a claimant must lose credits or be denied benefits where he has been compelled to terminate employment because such employment has resulted in a physical condition or disease likewise dangerous to health and personal safety."

29. An example of such inconsistency is Ben. Ser. 8069-Ala. $R$ (V6-7) where a 17year-old girl was disqualified for quitting a job which required her to walk four blocks alone after 1:00 a.m. from a streetcar line to her home but the Board of Appeals stated: "If such a job as this claimant quit were offered to her again, she would surely have a right to refuse it with good cause."

30. Ben. Ser. 7776-Conn. R (V6-1); Ben. Ser. 8826-Mich. A (V7-10); Ben. Ser. 4652Minn. A (V3-10); Ben. Ser. 4303-Ohio A (V3-8). Cf. Ben. Ser. 9312-Conn. R (V8-4).

31. Ben. Ser. 8117-Ky. R (V6-8) (failure to pay promised wage); Ben. Ser. 8027-Mass. $A(V 6-6)$ (failure to furnish transportation as agreed).

32. Ben. Ser. 8190-Iowa A (V6-10) (arbitrary deduction of day's pay); Ben. Ser. 8120-N. Y. R (V6-8) (discrimination in promotions); Ben. Ser. 7925-Ohio A (V6-4) (refusal of pass to dispensary); Ben. Ser. 7979-Ohio A (V6-5) (refusal of promised leave of absenco).

33. Ben. Ser. 7916-Conn. R (V6-4).

34. Ben. Ser. 8662-Cal. R (V7-8); Ben. Ser. 7069-Neb. R (V5-2); Ben. Ser. 7403W. Va. A (V5-6).

35. Ben. Ser. 8026-Maine A (V6-6).

36. Ben. Ser. 8903-La. A (V7-11); Ben. Ser. 8024-Maine A (V6-6); Ben. Ser. 8040S.D. R (V6-6).

37. Ben. Ser. 7815-Cal. R (V6-2); Ben. Ser. 7817-Fla. A (V6-2); Ben. Ser. 7826. Mich. A (V6-2); Ben. Ser. 8088-N.J. R (V6-8); Ben. Ser. 7976-N.Y. R (V6-5).

38. Teicher Unemployment Comp. Case, 154 Pa. Super. 250, 35 A. (2d) 739 (1944), 
It is sometimes contended that the objectives of unemployment compensation require that good cause for a severance of the employment relationship by the voluntary act of the claimant be limited to causes attributable to the employer or having some connection with the employment. Cases that have read such a limitation into the statutory language ${ }^{39}$ have taken what seems to be an unjustifiably restrictive view of the purposes of unemployment compensation. The main argument is that the statutory declaration of public policy states the objectives to be the protection of workers and of the state against the consequences of involuntary unemiployment by compelling the setting aside of reserves to be used for the benefit of persons who become unemployed through no fault of their oun. ${ }^{60} \mathrm{By}$ the usual rules of statutory construction, a general declaration of policy may be used to explain but not to contradict specific provisions of the act.41 Jurisdictions following this rule have refused to read into their statutes any restriction on good cause for voluntary learing. 42 Moreover, as brought out in the introductory section of this article, the recognition of good personal cause is consistent with the reference to "involuntary unemployment" and persons "unemployed through no fault of their own" in the statutory declarations of public policy, while refusal to recognize good personal cause is inconsistent with the general purpose of unemployment compensation. The recognition of good cause attributable to the employer shows that a strictly logical classification of unemployment as voluntary or involuntary is not the basic test of compensability. The same sort of social considerations which require the recognition of good cause attributable to the employer necessitate the recognition of good personal cause.

Ben. Ser. 8560-Pa. Ct. D (V7-5); Montgomery Ward \& Co. v. Board of Rev., Cools Cy. C. C., April 5, 1941, Ben. Ser. 6577-Ill. Ct. D (V1-10).

39. Woodmen of the World Life Ins. Society v. Olsen, 141 Neb. 776, 4 N. WV. (2d) 923 (1942), Ben. Ser. 7730-Neb. Ct. D (V5-12); John Morrell \& Co. v. Unemployment Comp. Comm., 13 N. W. (2d) 498 (S. D. 1914), Ben. Ser. 8859-S.D. Ct. D (V7-10); O'Neil Co. r. Board of Rev., Ohio Ct. of C. P., Summit Cy., March 12, 1940, Ben. Sar. 4\$22-Ohio Ct. D (V3-11).

40. Such statements are found in at least eighteen statutes. In addition at least eight acts refer to "involuntary unemployment" as the evil to be remedied, and two acts cpeal: of benefits for persons "unemployed through no fault of their own." However, eight statutes do not qualify the unemployment to be compensated by any such phrases and twelve acts contain no declaration of public policy.

41. 2 Sutherland, Statutes and Statutory Construction (2d ed. 1903) 8341; Black, Construction and Interpretation of L.1ws (2d ed. 1911) $\S 84$; Lauf v. E. G. Shinner \& Co., 303 U. S. 323 (1938); In re Steelman, 219 N. C. 306,13 S. E. (2d) 544 (1911).

42. See, e.g., Montgomery Ward \& Co. v. Board of Rev., Ill. C. C., Cools Cy., April 5, 1941, Ben. Ser. 6577-Ill. Ct. D (Vt-10); Teicher Unemployment Comp. Case, $154 \mathrm{~Pa}$. Super. 250, 35 A. (2d) 739 (1944), Ben. Ser. 8560-Pa. Ct. D (V7-5); Ben. Sar. 2314-Conn. R (V2-12); Ben. Ser. 4802-Fla. A (V3-11); Ben. Ser. 6107-Kan. A (V4-7); Ben. Sar. 6212Ky. R (V4-7); Ben. Ser. 7083-R.I. R (V5-2); Ben. Ser. 6592-Tenn. A (V4-10); Ben. Sar. 5332-Tex. A (V $1-2)$. 
The unintended social and economic evils which would result from reading restrictive words into the good cause provision have been aptly stated in an Illinois court decision ${ }^{43}$ in these words:

"Primarily, this sort of legislation is intended as a form of insurance against the rigors and hardships of unemployment, and nothing in this Act ought to be construed in such a way as to give employers advantages over their employees which they would not have but for this Act.

"Altogether too often, ameliorative measures, remedial measures, whose objects were known definitely by the legislature, become through strained construction, instruments detrimental to the very interests that the legislation aimed to protect. If the good grounds here spoken of were to be construed to mean grounds arising solely out of the employment itself, the Act in question would become a means of compelling servitude under the penalty of forfeiting certain benefits that are now granted by law to all citizens.

"It is no answer to say that in the absence of this legislation those benefits would not exist. Now they do exist. If these benefits could be taken from an employee simply because under the compulsion of domestic or personal conditions he leaves his employment, then the worker who relies upon these benefits, who finds in them a measure of security during the periods of unemployment would indirectly be tied to his job, compelled to hold it even under conditions which all reasonable men agree would justify his separating himself from it. Instead of being the remedial measure that is approved by all right thinking men, it would turn out to be a club in the hands of certain employers. It would tie the employee to his job. The employer could virtually say to him, "This job is inconvenient. Your own domestic situation, or your health, or other good causes counsel that you should abandon this job, but if you do, you will be deprived of the benefits which now under the law go to all workers who are without their fault unemployed.' I can't lend myself to the giving of such a construction to the Act."

Where good personal cause is recognized, the only requirement is that the claimant have acted as a reasonable person would have acted in the light of all the circumstances. ${ }^{44}$ These circumstances may include not only practical and financial incentives, such as an individual might have in obtaining or fitting himself for a better job, but purely psychological or emotional factors as well. As was stated by the Pennsylvania court in a recent case holding that a wife had good cause when she left her employment to join her soldier husband in another community:

43. Montgomery Ward \& Co. v. Board of Rev., Ill. C. C., Cook Cy., April 5, 1941, Ben. Ser. 6577-Ill. Ct. D (V4-10).

44. Ben. Ser. 8754-Ill. R (V7-9) (leaving to look after property in which life's savings were invested); Ben. Ser. 8781-Pa. R (V7-9) (leaving because of unsatisfactory living conditions); Ben. Ser. 9098-R.I. R (V8-1) (leaving because of reduction in wages). 
"It is difficult to conceive of a cause more impelling, more humanly justifiable, than the impulse which induces a devoted wife to spend with a husband, who is a member of the Armed Forces in time of war, what may prove to be the last days they shall ever have together on earth." 45

It is not anticipated that conversion from wartime to peacetime economy will create any special problems in the field of voluntary quit. There will be new variations in fact situations but no change in applicable principles. Some workers will undoubtedly quit war jobs in order to seek greater security in lines of work devoted to peacetime needs. If a lay-off is known to be imminent, it may be found that the vorker has good cause connected with the work; ${ }^{46}$ at any rate the quit will cease to be the cause of the unemployment as of the time lay-off would have occurred. Other workers who have moved to distant parts of the country in order to take war jobs may quit to return to their homes although their employer has converted to peacetime production and can continue to furnish employment. In some such cases distance from relatives or home property, after the special conditions due to the war have ceased, may make the job left unsuitable for the individual and thus constitute good cause connected with the work. In other cases additional factors, such as a reasonable prospect of work in the home community, would be necessary in order to find good cause.

Another situation which is likely to occur frequently in the conversion period and afterwards is a reduction in wages, or at least in take-home pay by the elimination of overtime. Whether a reduction in wages constitutes good cause for quitting depends upon consideration of all the circumstances in each case. Some of the factors to be considered are: the reasons for the reduction, whether it was a breach of contract, ${ }^{47}$ whether it was applied to all employees of the claimant's class, whether the employer gave notice of the decrease, ${ }^{43}$ whether the decrease was substantial, ${ }^{49}$ and the individual's prospects for work at a higher wage. Regardless of other factors, a worker has good cause for quitting when the reduced wage is less than the legal minimum, ${ }^{\mathrm{s}}$ less than the prevailing wage ${ }^{51}$ or less than a living wage. ${ }^{.2}$

45. Teicher Unemployment Comp. Case, 154 Pa. Super. 250, 35 A. (2d) 739 (1944), Ben. Ser. 8560-Pa. Ct. D (V7-5).

46. See note 30 supra.

47. Held good cause in Ben. Ser. 8117-Ky. R (V6-S). Cf. Ben. Ser. 8s37-N.Y. R (V7-

10) (increase in working hours with no increase in pay).

48. Ben. Ser. 7079-Ohio A (V5-2) (reduction without advance notice held good cause).

49. Held good cause in Ben. Ser. S107-Ill. R (V7-2); Ben. Ser. 5147-Mfass A (V4-1); Ben. Ser. \$245-Mich. A (V6-11); Ben. Ser. S037-R.I. A (V6-6); Ben. Ser. 70s0-R.I. A (V5-2).

50. Ben. Ser. 5321-Minn. A (V4-2).

51. Ben. Ser. 5135-Fla. A (V4-1).

52. Ben. Ser. \$902-Kan. A (V7-11); Ben. Ser. 5327-Tex. A (V1-2). 


\section{Misconduct.}

A determination that a claimant has been discharged for misconduct connected with the work involves four distinct findings: (1) that the claimant did the act alleged; (2) that the claimant was discharged; (3) that the act was the reason for the discharge; and, (4) that the act was "misconduct connected with the work."

1. Finding that claimant did act alleged. Mere general allegations of misconduct are not sufficient. ${ }^{53}$ Proof of a specific act is necessary.

A variation from ordinary problems of proof before an administrative body may be presented where a prior adjudication before a court or other administrative body has determined the question of commission of the act. Since the unemployment compensation body has the duty under its statute of making the determination for unemployment compensation purposes, a determination by another body cannot be conclusive. ${ }^{54}$ However, such a determination may be admitted in evidence where relevant and material. The test of relevancy is whether the former judgment decided the question at issue in the unemployment compensation hearing. For example, on the issue of disqualification for misconduct on the basis of a particular act for which the claimant has been prosecuted, a conviction is at least some evidence of commission of the act although not that the act constitutes misconduct connected with the work..$^{55}$ If the conviction has been ob. tained on a plea of guilty, the plea would be admissible in a court of law as an admission, subject of course to explanation. ${ }^{\text {t6 }}$ If the prior determination is found to be relevant and thus admitted, it would seem that the claimant should always be given an opportunity to explain it or to introduce rebutting evidence. The exclusion of material evidence resulting in prejudice to the appellant is ground for reversal of an administrative determination upon review by a court because of failure to grant a fair hearing. ${ }^{57}$ In other words, a determi-

53. Ben. Ser. 356-Wis. A (V1-3).

54. Ben. Ser. 8488-Minn. A (V7-4).

55. Ben. Ser. 6162-Tex. A (V4-7); Brit. Ump. 4569/26, Ben. Ser. (Gen. Supp. 1) BU-138; Brit. Ump. 98/28, Ben. Ser. (Gen. Supp. 1) BU-151; Brit. Ump. 5578/35, Ben. Ser. (Gen. Supp. 1) BU-120; Brit. Ump. 292/42.

56. 2 FREEMAN, JUdGMENTs (5th ed. 1925) § 1042; 2 Black. JudgMENTs (2d ed. 1902) $\S 529 ; 34$ C. J. 972 (1924).

57. People ex rel. Hirschberg v. Board of Supervisors of the County of Orange, 251 N. Y. 156, 172, 167 N. E. 204, 211 (1929), stating: "Though technical legal rules of evidence and procedure may be disregarded by administrative boards, when they act in a quasijudicial capacity, yet they must preserve the rights of those appearing before them to an adequate and fair hearing, and must act upon evidence which has some probative force." Accord: People ex rel. Packwood v. Riley, 232 N. Y. 283, 133 N. E. 891 (1922); People ex rel. Fallon v. Wright, 7 App. Div. 185, 40 N. Y. S. 285 (1st Dep't 1896), aff'd, 150 N. Y. 444, 44 N. E. 1036 (1896); Petak v. R. H. Macy \& Co., 254 App. Div. 617, 3 N. Y. S. (2d) 71 (3d Dep't 1938). 
nation by another body is never conclusive in the sense that other evidence can be excluded or disregarded.

2. Finding that claimant was discharged. The ordinary meaning of a discharge is a severance of the employment relation by the employer. However, where a worker has quit in anticipation of certain discharge (other than for lack of work $\mathrm{F}$ ), it is more reasonable to consider the termination of employment a discharge than a voluntary quit. ${ }^{\text {to }}$ The worker would then be disqualified only if the other elements of the disqualification for misconduct are present. The term "discharge" would not seem to include a suspension of a worker ${ }^{[9}$ although a number of statutes include suspensions for misconduct among the grounds for disqualification.

3. Finding that act was reason for discharge. As in the case of commission of the act, there is no disagreement over the legal content of the requirement, that a causal connection exist between the discharge and the claimant's act, and the only problem is one of proof. The determining body must be satisfied that the act stated to be the ground for the discharge was the true reason and not a mere pretext.

During the war the shortage of labor has had a tendency to reduce the number of discharges for trivial reasons. As competition for jobs becomes greater with the return of servicemen, there will be a temptation for employers to assign misconduct as the reason for termination of an individual's employment. Thether the termination was actually due to lack of work can usually be determined by whether or not the worker has been replaced. But some cases of replacement will be due to seniority rights, availability of more efficient workers, or pure favoritism, and a careful examination of the facts will be necessary in order to determine the real reason for the discharge.

4. Finding that act was "misconduct conneted with the work." The last and most troublesome question is whether the act constituted misconduct connected with the work. Acts which employers deem grounds for discharge range from breakage of an expensive machine or commission of a felony to a few minutes tardiness, smoking on the job, or failure to wear specified clothing. Unemployment compensation laws do not attempt to tell employers when they may or may not

58. An imminent lay-off is good cause for a voluntary quit. See note 30 stspra.

59. Ben. Ser. 1814-R.I. A (V2-7) (carelessness); Ben. Ser. 6530-Ohio R (V4-10) (marriage); Ben. Ser. 5333-Tex. R (V1-2) (non-payment of union dues).

60. Stitt v. Locomotive Engineers' Mutual Protective Ass'n, 177 Mich. 207, $142 \mathrm{~N}$. I:. 1110 (1913); Markey v. Schunl;, 152 Iowa 508, 132 N. W. 883 (1911). But Ese Ben. Sar. 1710-Ind. A (V2-7) applying a "discharge" disqualification to a suspencion

61. It is not necessary that the misconduct or reason for the discharge consigt of a single act. The act which occasions the discharge may be the culmination of a series, no one of which alone would be sufficient, but which talien together constitute miscondust connected with the work. Checker Cab Co. v. Industrial Comm., 242 Wis. 429, $3 \mathrm{~K}$. W. (2d) 286 (19.13), Ben. Ser. 8062-Wis. Ct. D (V6-7); Ben. Ser. 3137-Wis. A (V6-9). 
discharge workers; but the disqualification for a discharge applies only when that discharge was due to the worker's misconduct connected with his work. Because the consequences to the claimant are serious and the grounds for discharge often trivial, it is important that the determining body weigh carefully the question whether the act constitutes misconduct connected with the work.

An attempt to break down the concept of misconduct connected with the work into two parts, "misconduct" and "connected with the work," is in most instances not particularly helpful. The dictionary definition of misconduct is wrong or improper behavior. Behavior can be wrongful only in relation to some standard. For the purpose of the misconduct disqualification, that standard is to a large extent embodied in the limitation "connected with the work."

In the field of inefficiency and ordinary negligence, however, the applicable standard must be supplied from the general purpose of unemployment compensation rather than from the phrase "connected with the work." It is well established that inefficiency or ordinary negligence is not misconduct. The purpose of unemployment compensation requires that the disqualification be limited to intentional acts or negligence of equal culpability. As stated by the Wisconsin court:

"If mere mistakes, errors in judgment or in the exercise of discretion, minor and but casual or unintentional carelessness or negligence, and similar minor peccadilloes must be considered to be within the term 'misconduct,' and no such element as wantonness, culpability or wilfulness with wrongful intent or evil design is to be included as an essential element in order to constitute misconduct within the intended meaning of the term as used in the statute, then there will be defeated, as to many of the great mass of less capable industrial workers, who are in. the lower income brackets and for whose benefit the act was largely designed, the principal purpose and object under the act of alleviating the evils of unemployment by cushioning the shock of a lay-off, which is apt to be most serious to such workers." 62

Any argument that the misconduct disqualification is intended to prevent the payment of benefits to persons who have violated the criminal statutes or generally accepted moral standards is refuted by an analysis of the terms of the disqualification. Under the statutes, commission of an act of misconduct does not disqualify the claimant. There must have been a discharge by the employer because of that act. No matter how serious an individual's offense, the unemployment compensation law is not concerned with it in an instance where the employer has condoned the offense and later discharged the indi-

62. Boynton Cab Co. v. Neubeck, 237 Wis. 249, 258-9, 296 N. W. 636, 640 (1941), Ben. Ser. 6310-Wis. Ct. D (V4-8). 
vidual for lack of work. Moreover, it cannot be overemphasized that the disqualification is not for misconduct in general but for a particular kind of misconduct-misconduct connected with the work. . $^{\text {s. }}$

By what standard, then, is a worker's conduct to be measured? The standard to be applied is that of the employment contract, express or implied, which fixes the worker's duties in connection with his work. Since conduct can be wrong only when it riolates a duty to act otherwise, benefit decisions have held that an essential element of misconduct connected with the work is a breach of duty to the employer. ${ }^{64}$

On the other hand, breach of a duty to the employer does not alone make the act one "connected with the work" ${ }^{65}$ in the statutory sense. Certainly it would be inconsistent with the policy of the unemployment compensation laws to permit an employer to connect any behavior with the work simply by obtaining an express promise from the employee not to engage in that type of behavior. Eren duties which would be implied from the employment relation are not necessarily connected with the work within the meaning of the statutory disqualification. Whether or not they are part of the employment contract, rules for conduct off the job and off the premises are generally rules of selection or, as sometimes stated, conditions of employment.". They merely state the policy of the employer in respect to the hiring and retention of workers and give notice that workers whose retention

63. That unemployment compensation laws are not intended to supplement the criminal statutes or regulate morals was well put by a South Carolina Appeal Tribunal, Ben. Ser. 1985-S.C. A (V2-9), in holding that intoxication outside worlsing hours is not ground for disqualification:

"Inasmuch as it does not appear to have been the intent of the legislature to create by the passage of the Unemployment Compensation Act a las: regulating the morals of employees or supplementing the functions of regularly constituted peace officers within the State, it appears that moral considerations or breach of statute or ordinance not directly connected with employment are not within the purview of the Act as disqualifying factors."

Reaching the same conclusion in a similar situation, Ben. Ser. 36s5-K.C. R (V3-6), the North Carolina Unemployment Compensation Commission said:

"The utterance of truisms and gilded generalities on the evils of drinl: does not solve the problem. The matter is entirely objective, and the personal predilections, prejudices, and experiences of the investigator should not affect the rights of any of the interested parties. The Unemployment Compensation Law should not be converted into a beverage-control and an indirect prohibition law, however much we like good morals and right living; nor can we act [set] ourselves up as the mord arbiters of a mill community with the granting or withholding benefits as a club."

61. Boynton Cab Co. v. Newbeck, 237 Wis. 249, 296 N. W. 636 (1941), Ben. Ser. 6310-Wis. Ct. D (V4=S); Ben. Ser. 7182-Iova A (V5-4); Ben. Ser. S099-Fla. A (VG-S); Ben. Ser. 5268-Tex. A (V4-2); Ben. Ser. 7537-Colo. A (V5-9).

65. As already shown, the act must be vilful or culpably negligent. See page 162 siffra. The breach of duty must also be a material one. Ben. Ser. 7182-Iowa A (V5-4).

66. Ben. Ser. 31S2-N.C. R (V3-4); Ben. Ser. 7537-Colo. A (V5-9). See notes 70 and 71 infra (rules that workers will be discharged for arrest or wage garnishment). 
is inconsistent with the rules will be dismissed. It is immaterial that compliance or noncompliance with the conditions is in the control of the worker. An employee who fails to apply for citizenship papers in accordance with conditions imposed by the employer, ${ }^{67}$ or a woman who marries knowing that her employer does not employ married women and that she will be discharged, is not disqualified for misconduct connected with the work ${ }^{68}$ any more than an employee who is separated because he reaches an age above that fixed by company rules. ${ }^{69}$ Rules that a worker who is arrested ${ }^{70}$ or whose wages are subjected to garnishment ${ }^{71}$ will be discharged are also rules of selection.

It may be anticipated that rules of selection will play a more prominent part in benefit determinations during the postwar period than in previous years. As the reserve of unemployed persons becomes larger, employers tend to impose stricter job qualifications. Rules against the employment of married women and of persons above a certain age are especially likely to spring up during a depression period. Support for such rules is not always confined to employers. Because employers frequently allege misconduct in cases of discharge for failure to comply with rules of selection, claims-determining bodies will probably be called upon with increasing frequency to distinguish between rules of this character and rules of conduct.

The distinction between acts which may be justifiable grounds for discharge and acts which fall within the statutory disqualification as misconduct is well illustrated by a recent Florida case. An inspector in a plant making airplane parts had been discharged for falsifying questionnaires and applications for gasoline rationing. The employer argued that the misrepresentations were misconduct because they

67. See Ohio Ref. Dec. 808-Ref-42, May 1, 1942, CCH Unemployment Ins. Serv.Ohio 1 1970.016; Ohio Bd. of Rev. Dec. 25-BR-43, Jan. 13, 1943, ibid.

68. Ben. Ser. 492-Wis. A (V1-4); Ben. Ser. 2615-Mo. A (V3-1); Ben. Ser. 2623-Ohio A (V3-1); Ben. Ser. 3348-Iowa A (V3-5); Ben. Ser. 3530-Ohio A (V3-5); Ben. Ser. 4154-Cal. (V3-8); Ben. Ser. 6586-Ohio R (V4-10); Ben. Ser. 6550-Okla. A (V4-10).

69. Compare misrepresentation of age in securing employment as not constituting misconduct. Ben. Ser. 3669-Mo. A (V3-6). Even if such a misrepresentation be considered misconduct connected with the work, it is not the cause of the unemployment.

70. Ben. Ser. 3182-N.C. R (V3-4); Ben. Ser. 3683-N.C. R (V3-6); Ben. Ser. 5603. Tex. A (V4-4); Ben. Ser. 8171-Conn. R (V6-10). There may be some exceptional circumstances where a worker who is detained in jail could be found to be absent from work without good cause and therefore disqualified for misconduct connected with the work. In the ordinary situation, however, the causal connection between the commission of a criminal act and the subsequent absence from work due to arrest is too remote to justify a holding that the absence was wilful.

71. Ben. Ser. 605-N.Y. A (V1-5); Ben. Ser. 2448-Maine A (V3-1); Ben. Ser. 3684N.C. A (V3-6); Ben. Ser. 5375-Kan. A (V4-3); Ben. Ser. 2937-Ohio A (V3-3); Ben. Ser. 7760-Ohio A (V6-1); Ben. Ser. 8330-Mich. R (V7-1). Contra: Ben. Ser. 1081-Ind. A (V2-3); Ben. Ser. 7537-Colo. A (V5-9); Ben. Ser. 4152-Ala. A (V3-8). 
related to the claimant's fitness as a suitable employee in the capacity in which he was employed. An order of disqualification was reversed on appeal to the Board of Review.72 The Board stated:

"It is for the administrative agencies to determine whether the misconduct is actually 'connected with the work' as that term implies. The prerogative of an employer to conduct his business as he pleases, to make any lawful rules and regulations regarding the operation of his establishment, and to hire and fire employees under any circumstances and as he chooses, is readily acknowledged. However, if behavior is not related to or connected with the work, then a rule cannot make it so, nor can it supply the necessary element required by Statute.' . . .

"The misconduct alleged in the present case, no matter how serious, has not been shown to have occurred at the premises of the employer, or to have been of such a nature as to be detrimental to the employer's interests. Neither does it appear that the conduct in any way affected claimant's ability to perform his customary work in any less efficient manner than heretofore and we can but hold that the misconduct was not actually 'connected with his work' as that term implies."

The theory urged by the employer in the Florida case, that misconduct, although not occurring in the course of the employment, may be connected with the work if it evidences unsuitability for the work and makes retention of the worker incompatible with the employer's interests, seems unsound. "Suitability" is not a good test of connection with the work. It is a vague term and much broader in meaning than "connected with the work." Reasonable specifications of suitability for the job shade gradually into purely arbitrary requirements. To adopt the suitability theory would mean either accepting without question the judgment of employers as to what acts indicate qualification for a particular job or the determination by the agency in each case of what qualifications are reasonable. It may be reasonable to require that a bank teller not play the stock market on margin while in other jobs such a qualification would be entirely irrelevant, but there will be many intermediate cases which present close questions. In the same way, requirements as to marital status, age, sex, race, or creed are often purely arbitrary, but may in other instances have some relation to the job.

Standards of moral conduct would require particularly difficult determinations. A salesman for a public utility in a town of 5,000 who was seen drinking in public and traveling about with women other than his wife ${ }^{73}$ and a traveling representative of a livestock commission firm who was addicted to the use of intoxicating liquor and lived

72. Ben. Ser. 7900-Fla. A (V6-1).

73. Ben. Ser. 3930-Tex A (V3-7). 
for a time with a woman not his wife ${ }^{74}$ were disqualified for conduct causing the employing company loss of good will and reflecting on its reputation. The preferable view that misconduct which does not take place in the course of the employment is not connected with the employee's work even though it may affect the employer's business adversely is illustrated by decisions in Maryland and Ohio refusing to disqualify a theater usher who was "involved with" girls on probation from reform school ${ }^{75}$ and a truck driver for a department store who was convicted of window peeping. ${ }^{76}$ In a well-considered Texas case an employee of a company operating an oil well had been convicted of theft of joints of pipe belongirig to a pipe line company operating on the same land. The commission held, reversing the initial determination, that no disqualification could be invoked "because the misconduct, if any, was not committed against the employer, nor was it committed while claimant was engaged in performing services for his employer, nor was it in any way connected with his employment." "77

The concept of connection with the work is one which can best be delimited by the gradual process of inclusion or exclusion as the cases arise, rather than by an attempt to frame a precise definition. Circumstances to be considered are whether the act occurred during the hours of employment, whether it occurred on the employer's premises, whether it occurred while the employee was engaged in his work, and whether the employee took advantage of the employment relation in order to commit the act. However, the presence or absence of any one of these circumstances is not conclusive. Above all, as the Florida Board of Review has made clear, neither violation of the employer's rules nor failure to meet the employer's standards of suitability for the job can be accepted as determinative of misconduct connected with the work.

74. Ben. Ser. 4891-S.D. A (V3-12).

75. Ben. Ser. $1863-\mathrm{Md}$. A (V2-8).

76. Ben. Ser. 2058-Ohio A (V2-10). See also Ben. Ser. 92-Wis. A (V1-1) (act of indecency by truck driver); Ben. Ser. 2147-N.Y. R (V2-11) (sex offense by doorman of clothing store); Ben. Ser. 2859-Ind. A (V3-3) (incest).

77. Ben. Ser. 5268-Tex. A (V4-2). If the evidence in this case had shown that the worker took advantage of his employment relation to gain access to the premises or knowledge enabling him to commit the theft, the act might have been found connected with the work on that ground. 